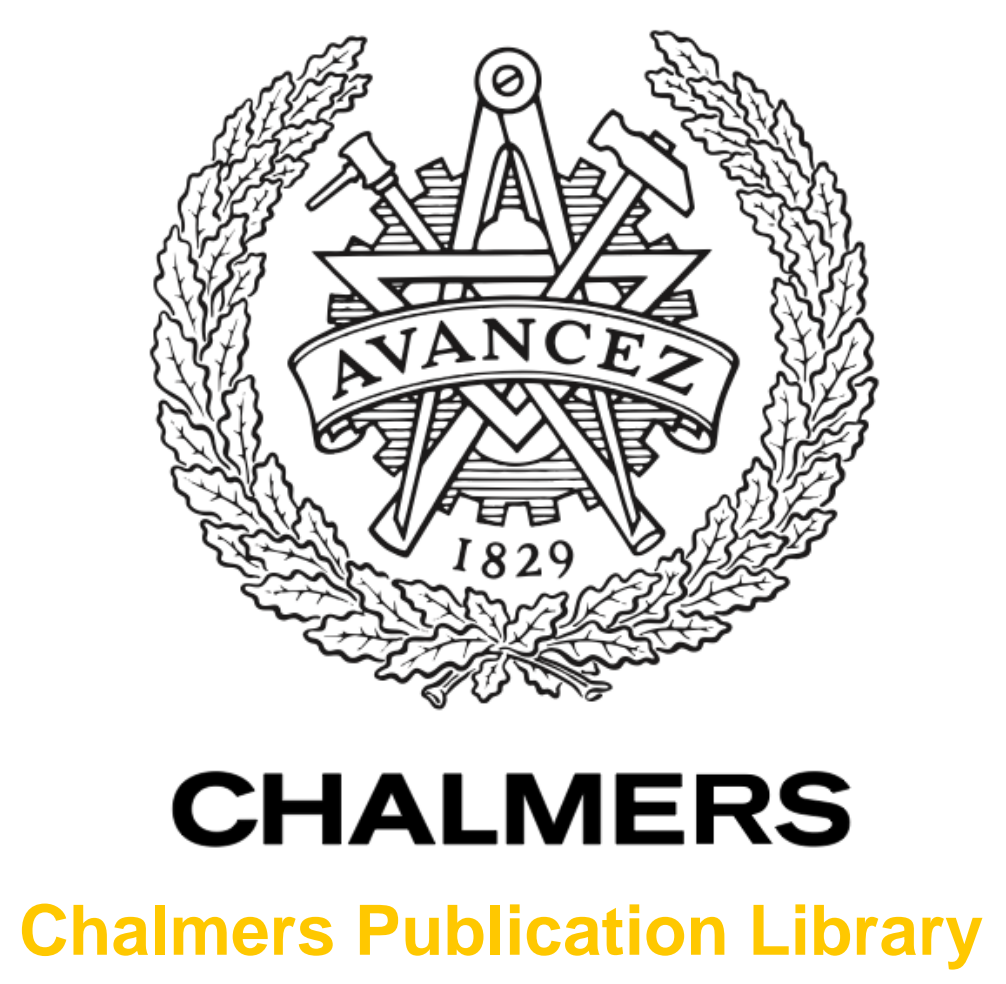
Influence of the N: P supply ratio on biomass productivity and time-resolved changes
in elemental and bulk biochemical composition of Nannochloropsis sp.

This document has been downloaded from Chalmers Publication Library (CPL). It is the author's version of a work that was accepted for publication in:

Bioresource Technology (ISSN: 0960-8524)

Citation for the published paper:

Mayers, J. ; Flynn, K. ; Shields, R. (2014) "Influence of the N: P supply ratio on biomass productivity and time-resolved changes in elemental and bulk biochemical composition of Nannochloropsis sp.". Bioresource Technology, vol. 169 pp. 588-595.

http://dx.doi.org/10.1016/j.biortech.2014.07.048

Downloaded from: http://publications.lib.chalmers.se/publication/241597

Notice: Changes introduced as a result of publishing processes such as copy-editing and formatting may not be reflected in this document. For a definitive version of this work, please refer to the published source. Please note that access to the published version might require a subscription. 


\title{
Influence of the N:P supply ratio on biomass productivity and time-resolved changes in elemental and bulk biochemical composition of Nannochloropsis sp.
}

\author{
Joshua J. Mayers, Kevin J. Flynn*, Robin J. Shields \\ Centre for Sustainable Aquatic Research, Swansea University, Swansea SA2 8PP, UK
}

\section{H I G H L I G H T S}

- Effect of N + P supply on Nannochloropsis sp. growth dynamics and chemical content.

- Detailed and comprehensive batch culture data series for support of modelling.

- Cellular $\mathrm{N}$ main driver of lipid accumulation, with lesser effect of P starvation.

- P usage can be halved (to N:P of 32:1) with no significant effect on productivity.

- Maximum lipid content and concentration of 52\% DW and $230 \mathrm{mg} \mathrm{L}^{-1}$, respectively.

\section{A R T I C L E I N F O}

\section{Article history:}

Received 21 March 2014

Received in revised form 8 July 2014

Accepted 13 July 2014

Available online 18 July 2014

\section{Keywords:}

Microalgae

Nannochloropsis sp.

Phosphorus usage

Lipid accumulation

Nitrogen deficiency

\begin{abstract}
A B S T R A C T
This work reports for the first time the detailed impacts of dual nitrogen $(\mathrm{N})$ and phosphorus $(\mathrm{P})$ stress on growth dynamics and biochemical composition in the Eustigmatophyte Nannochloropsis sp. P-stress concurrent with $\mathrm{N}$-stress had subtle effects on culture bulk biochemical composition, but negatively influenced biomass productivity. However, the N:P supply ratio can be raised to at least 32:1 without compromising productivity (yielding a maximum lipid content of $52 \%$ of dry weight and volumetric lipid concentration of $\left.233 \mathrm{mg} \mathrm{L}^{-1}\right)$. The maximum biomass and lipid yields per unit of cell-P were $1.2 \mathrm{~kg} \mathrm{DW}$ $(\mathrm{g} \mathrm{P})^{-1}$ and $0.54 \mathrm{~kg}$ lipid $(\mathrm{g} \mathrm{P})^{-1}$. The $\mathrm{P}$ concentration of many common media is thus in surplus for optimal Nannochloropsis sp. biomass and lipid production, offering potential for significant savings in $\mathrm{P}$ usage and improving the sustainability of algal cultivation.
\end{abstract}

(c) 2014 Elsevier Ltd. All rights reserved.

\section{Introduction}

Balancing nutrient supply is critical for optimising microalgal composition and commercial viability. Single nutrient depletion (typically of nitrogen (N); Adams and Bugbee, 2014) is often used to alter or enhance biochemical content, with other nutrients such as phosphorus (P) added to excess. This practice wastes expensive resources and contributes to pollution. Here, for the first time, we describe how manipulating the N:P supply can simultaneously be used to control production and minimise nutrient wastage in the commonly used microalga, Nannochloropsis.

Life cycle analyses have highlighted the significant impact that nutrient demand can have upon the environmental and economic impact of large-scale microalgal cultivation (Handler et al., 2012;

\footnotetext{
* Corresponding author. Tel.: +44 1792205726.

E-mail address: K.J.Flynn@swansea.ac.uk (K.J. Flynn).
}

Johnson et al., 2013; Sills et al., 2013; Yang et al., 2011). P is an essential macronutrient, being a component of nucleic acids, phospholipids and phosphorylated sugars, as well as being critical in cellular energy metabolism and modulating protein function (e.g., for microalgae, Moseley and Grossman, 2009). In microalgae, P typically accounts for $<1 \%$ of cell dry weight, but attains ca. $4 \%$ under circumstances allowing "luxury uptake" (Powell et al., 2009).

Johnson et al. (2013) recently calculated that N-based fertilizers require between 50 and $113 \mathrm{MJ} \mathrm{kg-N^{-1 }}$ in fossil energy and produced between 3.9 and $9.2 \mathrm{~kg}$ of $\mathrm{CO}_{2} \mathrm{~kg}-\mathrm{N}^{-1}$ for different products (ammonium nitrate, urea or urea-ammonium nitrate blends). Calculations for P are complex, due to phosphate rock mining and the convoluted production and shipping processes. However, direct energy inputs for P-containing fertilisers such as monoand diammonium phosphate may be estimated at between 56 and $64 \mathrm{MJ} \mathrm{kg-P}^{-1}$ (calculated from Johnson et al., 2013, and 
references therein, including EFMA, 2000; Handler et al., 2012). Moreover, the economic if not energetic costs for the supply of P-fertilizers are sure to increase given that readily available mineral deposits of $P$ are forecast to be exhausted within the next 100 years (Cordell et al., 2009). Already the price of phosphorus rock has increased from a stable level of around $\$ 40 \mathrm{t}^{-1}$ in 2006 to above $\$ 100 \mathrm{t}^{-1}$ by the end of 2013 ("Historical Phosphate Rock Prices and Price Chart - InvestmentMine" 19/2/14), with a significant spike in $2008\left(>\$ 400 \mathrm{t}^{-1}\right)$ due to a sudden increase in oil prices (Cordell et al., 2011). The spatial imbalance in global P reserves and geo-political instability are additional factors likely to affect supply and pricing (Elser and Bennett, 2011).

Nutrient supply is thus expected to become a serious issue over the coming decades, significantly impacting a number of industries and agricultural sectors, and inevitably affecting the commercial viability of microalgal biomass production (Britton and Baur, 2010; Shilton et al., 2012). The National Research Council of the National Academies (U.S.A.) in a 2012 report on the production of algal biofuels in the U.S.A., highlighted the need for more clear indicators of sustainability with regards to resource use, proposing that general indicators of nutrient requirement to produce volumes of dry biomass and volumes of fuel be measured and compared. For example, $0.71 \mathrm{~kg} \mathrm{P}$ is required to generate $1 \mathrm{~kg}$ of biodiesel from microalgae (Yang et al., 2011). It is hence critical to develop strategies where both biomass production and product composition is optimised in relation to nutrient utilisation.

There have been many studies on the impacts of single nutrient stresses on microalgae, mostly concerning N-stress (Adams and Bugbee, 2014; Hu and Gao, 2006). Fewer studies have investigated the effect of different $P$ regimes on growth and biochemical composition for several species of microalgae (Chu et al., 2013, 2014; Roopnarain et al., 2014; Ruangsomboon et al., 2013; Wu et al., 2012, 2013). These report differing conclusions on the role of P-limitation in algal physiology, and in particular for lipid accumulation. A key factor complicating the interpretation of $\mathrm{N}$ vs $\mathrm{P}$ stress impacts is that the relationship between stress, as indicated by the elemental quotas, and growth rate differs between these nutrients. Thus the relationship between growth and $\mathrm{N}: \mathrm{C}$ is linear, while for $\mathrm{P}: \mathrm{C}$ it is distinctly non-linear, and that while $\mathrm{P}: \mathrm{C}$ may increase during $\mathrm{N}$-stress, $\mathrm{N}: \mathrm{C}$ can decrease during P-stress even with excess $\mathrm{N}$-nutrient availability (Flynn, 2008).

There are very few studies of coupled N-P stress in which a suite of biochemical parameters have been measured, a factor that severely limits our ability to understand and thence model microalgal growth (Flynn, 2008) and explore productivity scenarios (Kenny and Flynn, 2014). Accordingly, this study investigates the growth dynamics and biochemical composition of the widely used marine Nannochloropsis sp. for the first time under different phosphate supply regimes, in which the N:P nutrient supply ratios ranged from 16:1 to $80: 1$.

\section{Methods}

\subsection{Algae strain and culture conditions}

The marine Eustigmatophyte microalga Nannochloropsis sp. (CCAP 211/78) was batch cultivated in $10 \mathrm{~L}$ tubular airlift photobioreactors (PBR; acrylic plastic, $0.1 \mathrm{~m}$ diameter/light path, $1.2 \mathrm{~m}$ height). Reactors were maintained at $22 \pm 1^{\circ} \mathrm{C}$, and aerated with filtered $(0.2 \mu \mathrm{m})$ ambient air (i.e., $0.039 \% \mathrm{CO}_{2}$ ) at a rate of $0.1 \mathrm{~L} \mathrm{~L}^{-1}(\mathrm{v} / \mathrm{v})$ into the base of the tube through a $1 \mathrm{~mm}$ i.d. plastic capillary tube. Bioreactors were illuminated at $100 \mu \mathrm{mol}$ photons $\mathrm{m}^{-2} \mathrm{~s}^{-1}$ PAR (reactor surface) using daylight fluorescent tubes
(T8, $58 \mathrm{~W}$ ) mounted perpendicular to the bioreactors, and operated under a light:dark cycle of 18:6 h. Irradiance was measured using a cosine-corrected light meter (WALZ ULM-500).

Cultures were grown on modified Walnes media (Andersen, 2005), with $\mathrm{NaNO}_{3}$ and $\mathrm{KH}_{2} \mathrm{PO}_{4}$ as the macro-nutrients (see below for concentrations). The seawater base was natural, pumped from Swansea Bay (U.K.), filtered to $1 \mu \mathrm{m}$, UV treated and ozonated. Salinity was $30( \pm 2)$. $\mathrm{pH}$ was maintained between 7.8 and 8 by addition of $10 \mathrm{mM}$ Tris- $\mathrm{HCl}$ (Melford Chemicals). Inocula for the growth experiments were grown in the same PBR set-up and then diluted to give a starting concentration of $2 \times 10^{6}$ cells $\mathrm{mL}^{-1}$. Relative to the final yield, these inocula were ca. $5 \%$ of the maximum final cell density, contributing approximately $1.0 \mathrm{mg}$ biomass$\mathrm{N} \mathrm{L}^{-1}$ and $0.11 \mathrm{mg}$ biomass-P L ${ }^{-1}$.

\subsection{Experimental design}

Nannochloropsis sp. was cultivated in nutrient media with 4 different N:P molar ratios, 16:1, 32:1, 64:1 and 80:1 (1.38, 0.69, 0.35 and $\left.0.028 \mathrm{mg} \mathrm{P} \mathrm{L}^{-1}\right)$. The nutrient-N content was fixed at $10 \mathrm{mg} \mathrm{N} \mathrm{L}^{-1}(714 \mu \mathrm{M} \mathrm{N})$, with the P content adjusted accordingly. Batch culture experiments were run for 10 days, with each treatment repeated at least 3 times. The use of samples grown under a variety of nutrient regimes and harvested at different time points throughout the batch culture, yielded biomass samples of various biochemical composition.

\subsection{Analytical techniques}

\subsubsection{Analysis of growth dynamics}

Cell number, total cellular volume and cell size were recorded daily using a Coulter counter (C4 Beckman Coulter GmBH, Drefield, Germany). Dry weight (DW) was determined by filtering a known volume of culture onto precombusted GF/F Whatman filters (GE Healthcare, Germany). Filters were washed with ammonium formate $(0.5 \mathrm{M})$ to remove salts, then dried for at least $18 \mathrm{~h}$ at $70{ }^{\circ} \mathrm{C}$, before cooling at room temperature in a desiccator. On a routine basis, DW was estimated from the Coulter counter-derived biovolume (i.e. total cellular volume) using a previously established calibration of $1 \mathrm{~mL}$ biovolume $=1 \mathrm{~g}$ DW.

Biomass-specific growth rate was calculated from changes in the biomass concentration ( $\mathrm{mg} \mathrm{DW} \mathrm{L}^{-1}$ ) using the following equation:

$\mu=\frac{\ln N_{1}-\ln N_{0}}{t_{1}-t_{0}}$

where $N_{0}$ and $N_{1}$ are the biomass concentrations at times $t_{0}$ and $t_{1}$. The observed exponential (maximum) growth rate $\left(\mu^{\text {exp }}, \mathrm{d}^{-1}\right)$ was calculated over the first 4 days of growth (0-4 days).

\subsection{2. $C, N$ and $P$ elemental composition}

Elemental $\mathrm{C}$ and $\mathrm{N}$ content was determined using an elemental analyser interfaced with an isotope ratio mass spectrometer, according to the method described in Mayers et al. (2013); all measurements were made in duplicate. Cellular-P content was measured by digesting cells, from a known volume of culture collected upon pre-combusted $13 \mathrm{~mm} \mathrm{A/E}$ glass fibre filter (Pall Corporation, NY, USA), using the acidic persulfate digestion method $\left(0.015 \mathrm{M} \mathrm{K}_{2} \mathrm{~S}_{2} \mathrm{O}_{6}\right.$ plus $0.018 \mathrm{M} \mathrm{H}_{2} \mathrm{SO}_{4}$, autoclaved at $121{ }^{\circ} \mathrm{C}$ for $75 \mathrm{~min}$ ). Cellular-P was converted to free orthophosphate and measured spectrophotometrically using an ammonium molybdate assay at $880 \mathrm{~nm}$ (Strickland and Parsons, 1968). 


\subsection{Nutrient analysis}

\subsubsection{Fourier-transform infrared spectroscopy (FTIR) biochemical determination}

The content of lipid, protein and carbohydrate in biomass samples was determined using FTIR, using the method described in Mayers et al. (2013). Briefly, freeze-dried algal biomass was finely powdered and spectra measured on a PerkinElmer Spectrum Two instrument equipped with a diamond crystal iATR reflectance cell with a DTGS detector scanning over the wavenumber range of $4000-450 \mathrm{~cm}^{-1}$ at a resolution of $4 \mathrm{~cm}^{-1}$. Three replicates (each of 10 scans averaged) for each sample were taken and the results averaged. Background correction scans of ambient air were made prior to each sample scan. Scans were recorded using the PerkinElmer spectroscopic software Spectrum and quantification methods had been previously built in SpectrumQuant (version 10. PerkinElmer, Germany). Ethanol (60\% v/v) was used to clean the diamond ATR between samples.

\subsection{Statistical analysis}

Differences in treatments were assessed by one-way analysis of variance (ANOVA). If ANOVA results were significant $(p<0.05)$, comparisons between means were made using Tukey's Post Hoc Analysis. Statistical analyses were conducted using the software $\mathrm{R}$ (version 0.97.551).

\section{Results and discussion}

\subsection{Effect of nutrient supply $N: P$ ratio on batch growth dynamics}

The pattern of batch growth is shown in Fig. 1; all treatments starting with the same initial $\mathrm{N}$ concentration $\left(10 \mathrm{mg} \mathrm{N} \mathrm{L}^{-1}\right)$, but with varied $\mathrm{P}$ supplementation $(1.38,0.69,0.35$ and $\left.0.028 \mathrm{mg} \mathrm{P} \mathrm{L}^{-1}\right)$. For the first 4 days of cultivation Nannochloropsis sp. grew exponentially at similar rates $\left(\mu^{\exp } \sim 0.6 \mathrm{~d}^{-1}\right.$; Fig. 1D; Table 1), except those grown at a supply N:P ratio of 80 , which grew significantly slower. Cell division had markedly slowed in the $80: 1$ treatment by day 4 , whereas the $64: 1$ treatment began to slow by day 5 (Fig. 1A). The 16:1 and 32:1 treatments attained similar maximum biomass concentrations, which were significantly greater than the $64: 1$ and $80: 1$ treatments $(p<0.05$; Fig. 1C), with no difference between these latter two treatments. The maximum biomass productivity over this period ranged from 45.4 to $56.6 \mathrm{mg} \mathrm{DW} \mathrm{L}^{-1} \mathrm{~d}^{-1}$, with the $80: 1$ treatment having a significantly lower productivity then the other treatments (Table 1 ). Similar trends to those seen for biomass were also seen in cell density, with the exception that the maximum cell density of the 80:1 treatment was significantly lower than those grown 64:1 $\mathrm{N}: \mathrm{P}$, as well as the $32: 1$ and $16: 1$ treatment $(p<0.01$; Fig. $1 \mathrm{~A})$. These results would suggest that the $64: 1 \mathrm{~N}: \mathrm{P}$ treatment provided adequate $\mathrm{P}$ for exponential growth but became P-stressed shortly after exhaustion of the $\mathrm{N}$ source, whereas supply $\mathrm{N}: \mathrm{P}$ ratios $\sim \geqslant 64: 1$ significantly effected growth.

Rapid depletion of extracellular-P and the subsequent decrease in cellular-P have been previously shown to cause immediate decreases in cell division rates (Wu et al., 2012). Despite the cessation of cell division at earlier time points, both the 64 and 80:1 treatments continued to increase in biomass concentration past these points. Only the 80:1 treatment showed a significant increase in cell size compared to other treatments, becoming apparent from day 6 onwards (Fig. 1B), eventually reaching a cell volume 1.7-1.9-fold greater on day 10 . All other N:P supply treatments had cells of approximately the same size. The increase in cell size with P-stress, implicating restrictions in the cell cycle at
S-phase, is an important feature of microalgal growth and one which complicates greatly the analysis of cell-quota (as distinct from C-quota) relationships with growth rate (Flynn, 2008). No previous reports in the literature for the increase in cell size due to P-limitation have been seen in Nannochloropsis sp., but it is likely to be a result of the accumulation of carbon products. A culture approach that deliberately increased cell size could be beneficial from a processing point of view, were harvesting may be more efficient, particularly by membrane filtration (Gerardo et al., 2014).

$\mathrm{N}$ and $\mathrm{P}$ uptake were measured as the amount assimilated into biomass over the course of the experiment. The maximum $\mathrm{N}$ uptake per unit biomass per day did not vary significantly between treatments and was between 0.027 and $0.029 \mu \mathrm{g} \mathrm{N} \mathrm{DW}^{-1} \mathrm{~d}^{-1}$ (Table 1). The maximum rate of $\mathrm{N}$ uptake occurred between days 2 and 4 in the higher $\mathrm{P}$ treatments, in which $\mathrm{N}$ was $>95 \%$ removed in the first 4 days, while the maximum uptake in the $80: 1$ treatment was between days 0 and 2, with these cells not achieving $>95 \%$ of $\mathrm{N}$ removal until day 6 (Supplementary Information Fig. 1A).

The maximum rate of $\mathrm{P}$ uptake per unit biomass was positively related to the level of $\mathrm{P}$ supplied (Table $1 ; r^{2}=0.92, p<0.001$ ). The lowest $\mathrm{P}$ treatment $(\mathrm{N}: \mathrm{P}$ 80:1) exhausted $\mathrm{P}$ by day 6 , with a decreased growth rate in the days preceding that time (Fig. 1D) and a rapid cessation of cell division after day 6 (Fig. 1A). The other treatments exhausted $P$ by between day 6 and 10 (Supplementary Information Fig. 1B). P removal in the 16:1 treatment between days 0 and $2\left(14.1 \mu \mathrm{g} \mathrm{PW}^{-1} \mathrm{~d}^{-1}\right.$, Table 1$)$ was 1.7 and 1.5 -fold greater then that of the other treatments, with no significant difference in biomass concentration, except in the case of the lowest $\mathrm{P}$ level. The results were consistent with a "luxury uptake" of P in the highest supplied treatment (Powell et al., 2009), and could represent a potential wasted consumption of a costly fertiliser.

\subsection{Biochemical composition under different nutrient regimes}

Changes in the bulk biochemical composition of Nannochloropsis strains, with regards to the accumulation of lipid under severe nitrogen stress, have been reported previously (Adams and Bugbee, 2014; Hu and Gao, 2006). However, no studies have investigated the effect of $\mathrm{N}$ :P supply stoichiometry on the dynamics of cellular $\mathrm{C}: \mathrm{N}: \mathrm{P}$ and thence on bulk biochemical composition shifts in detail. Here, growth in a batch mode with different initial nutrient-P concentrations but a set nutrient- $\mathrm{N}$ concentration reveals the subtle effect of P-limitation on biochemical composition.

All treatments had an initial lipid content of between $31 \%$ and 34\% DW (Fig. 2B), consistent with the start inocula having recently entered into $\mathrm{N}$-stress. In the first 2 days, when $\mathrm{N}$ was readily available and the cell $\mathrm{N}$-status thus became replete, there was an increase in biomass protein content, with a corresponding decrease in carbohydrate and lipid content (expressed as \% DW). Protein content subsequently dropped during $\mathrm{N}$-stress to values between $17 \%$ and $20 \%$ DW on day 10 across treatments. Overall, there was no significant difference in the volumetric concentration $\left(\mathrm{mg} \mathrm{L}^{-1}\right)$ of protein between treatments (Fig. 2D). This pattern was expected due to the same level of $\mathrm{N}$ provided in the culture media (10 $\mathrm{mg} \mathrm{N} \mathrm{L}^{-1}$ ), effectively limiting the maximum size of the protein pool. Once media $\mathrm{N}$ was exhausted and net protein synthesis ceased, the protein pool was subsequently split between cells upon division, up until a critical threshold was reached and growth stopped. Protein as a\% DW is hence effectively diluted by continued accumulation of carbon fixation products. In the context of $\mathrm{N}$-quota kinetics, growth halts when the N-quota (here described as protein as \% DW) attains its minimum value (Flynn, 2008). However, the degree of P-stress affected the dynamics of that event.

From day 4, following $\mathrm{N}$ depletion, all treatments showed a characteristic increase in lipid content (1.6-1.9-fold increase per 

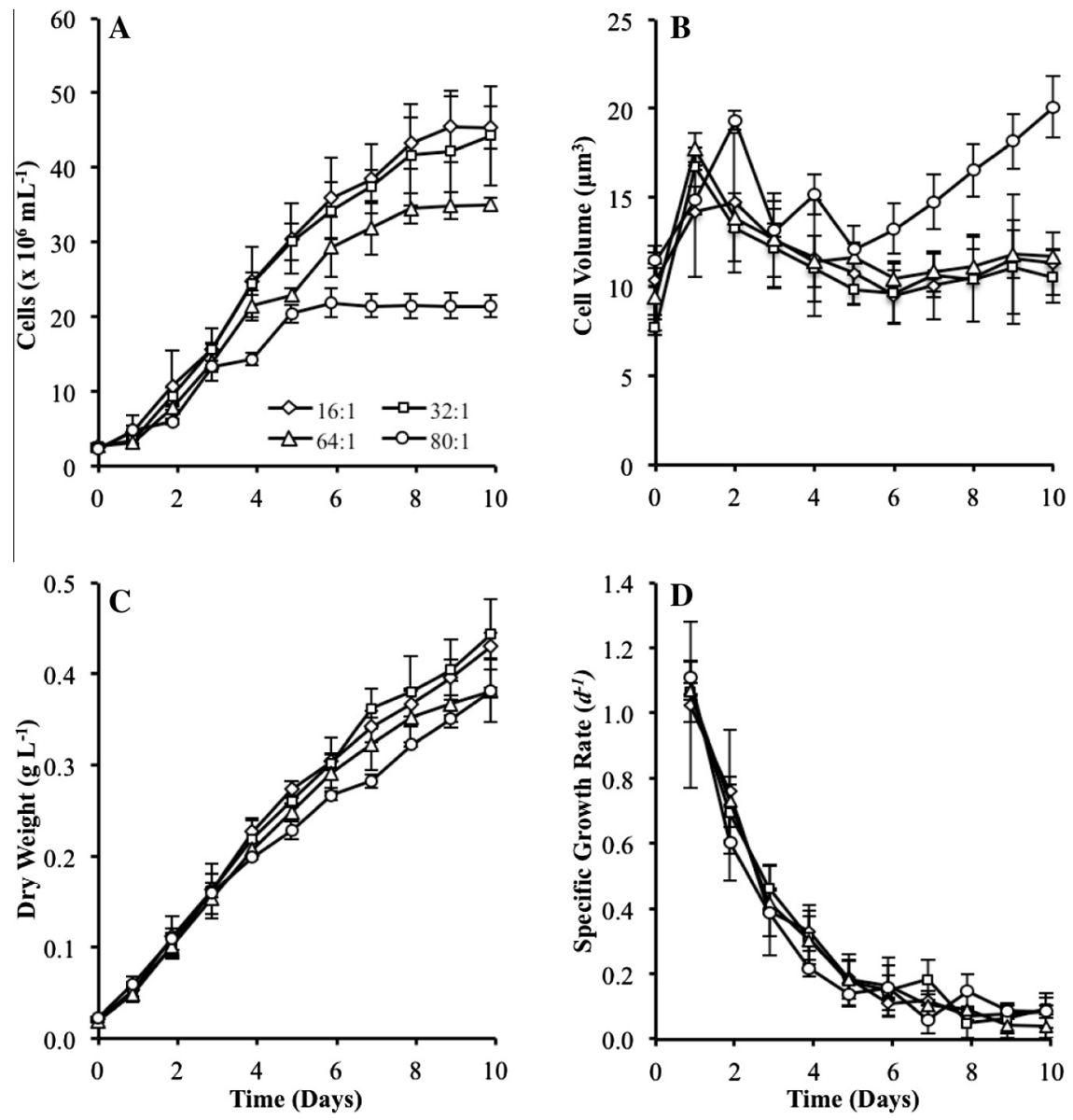

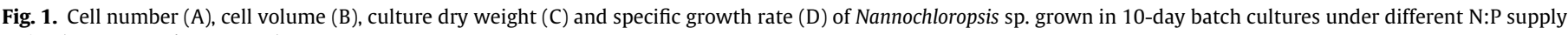
ratios $(n=3$, error bars $=1 \mathrm{SD})$.

Table 1

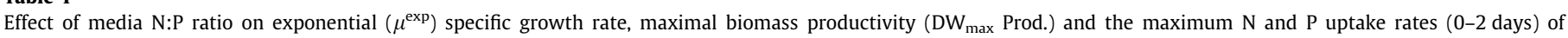
Nannochloropsis sp. during 10-day batch cultures.

\begin{tabular}{|c|c|c|c|c|}
\hline Parameter & $16: 1$ & $32: 1$ & $64: 1$ & $80: 1$ \\
\hline$\mu^{\exp }\left(\mathrm{d}^{-1}\right)$ & $0.62 \pm 0.01^{\mathrm{a}}$ & $0.62 \pm 0.02^{\mathrm{a}}$ & $0.60 \pm 0.01^{\mathrm{a}}$ & $0.56 \pm 0.01$ \\
\hline $\mathrm{DW}_{\max }$ productivity $\left(\mathrm{mg} \mathrm{L}^{-1} \mathrm{~d}^{-1}\right)$ & $56.6 \pm 2.21^{\mathrm{a}}$ & $52.3 \pm 0.44^{b}$ & $50.5 \pm 1.52^{b}$ & $45.4 \pm 0.48^{c}$ \\
\hline $\mathrm{N}$ uptake rate $\left(\mu \mathrm{g} \mathrm{N} \mathrm{mg} \mathrm{DW}^{-1} \mathrm{~d}^{-1}\right)$ & $28.9 \pm 2.82^{\mathrm{a}}$ & $27.5 \pm 1.50^{\mathrm{a}}$ & $26.5 \pm 2.96^{\mathrm{a}}$ & $26.5 \pm 1.13^{\mathrm{d}}$ \\
\hline P uptake rate $\left(\mu \mathrm{g}\right.$ P mg DW $\left.{ }^{-1} \mathrm{~d}^{-1}\right)$ & $1.41 \pm 0.05^{\mathrm{a}}$ & $0.93 \pm 0.06^{b}$ & $0.84 \pm 0.09^{b}$ & $0.70 \pm 0.04^{c}$ \\
\hline
\end{tabular}

Significant differences between treatments are represented by different letters (One-way ANOVA with post hoc LSD, $p<0.05$ ).

unit DW, Fig. 2B) concurrent with a (i.e., balanced by) a halving of protein per unit DW (Fig. 2A). Lipid accumulation slowed by day 9 and 10 , attaining a plateau of $46-53 \%$ DW as lipid. On a volumetric basis the $64: 1$ and $80: 1 \mathrm{~N}: \mathrm{P}$ treatments had a significantly lower lipid concentration from day 8 onwards (Fig. 2E), with the $16: 1$ and $32: 1$ regimes attaining a maximum of approximately $230 \mathrm{mg}$ lipid $\mathrm{L}^{-1}$ on day 10 . This increase in lipid concentration reflects the continuing accumulation of lipids per unit biomass coupled with the continuing increase of biomass per unit culture.

The $16: 1$ and $32: 1 \mathrm{~N}: \mathrm{P}$ treatments did not vary significantly with respect to lipid production rates, with both reaching a maximum on day 8 , of $22-23 \mathrm{mg} \mathrm{L}^{-1} \mathrm{~d}^{-1}$. The higher $\mathrm{N}$ :P treatments achieved lower levels of productivity. A cellular $\mathrm{N}: \mathrm{P}$ ratio of $16: 1$ is typically held as being optimal (Geider and La Roche, 2002). If the aim of cultivation is lipid production, then the $32: 1 \mathrm{~N}: \mathrm{P}$ ratio treatment may represent a move favourable option for production of Nannochloropsis sp., as there is no increase in productivity at higher supply levels, whereas ratios approaching 64:1 begin to show decreased productivities. Additionally, from a process optimisation point of view, harvesting a dense culture $\left(\mathrm{g} \mathrm{DW} \mathrm{L}^{-1}\right)$ is a more attractive scenario than harvesting a low density equivalent when considering many common harvesting techniques. Subsequently, at large scales of cultivation, even small differences in biomass concentration (or in cell size; Fig. 1C) may result in changes in costs and energy usage for downstream processing (Greenwell et al., 2010). To achieve greater biomass concentrations and further decrease downstream processing costs, greater quantities of $\mathrm{N}$ and $P$ can be added at these ratios. However, the effects of decreased light per cell/unit biomass (assuming the same light energy input) may affect bulk biochemistry, in particular decreasing the rate of lipid accumulation under $\mathrm{N}$-stress due to decreased carbon fixation rates. This affects bioreactor design and operation (Kenny and Flynn, 2014).

Carbohydrate content followed the same pattern as lipids, being accumulated concurrently as protein content decreased, albeit to lower levels (Fig. 2C). Cells in the 80:1 N:P treatment had a significantly greater carbohydrate content than those in the 16:1 

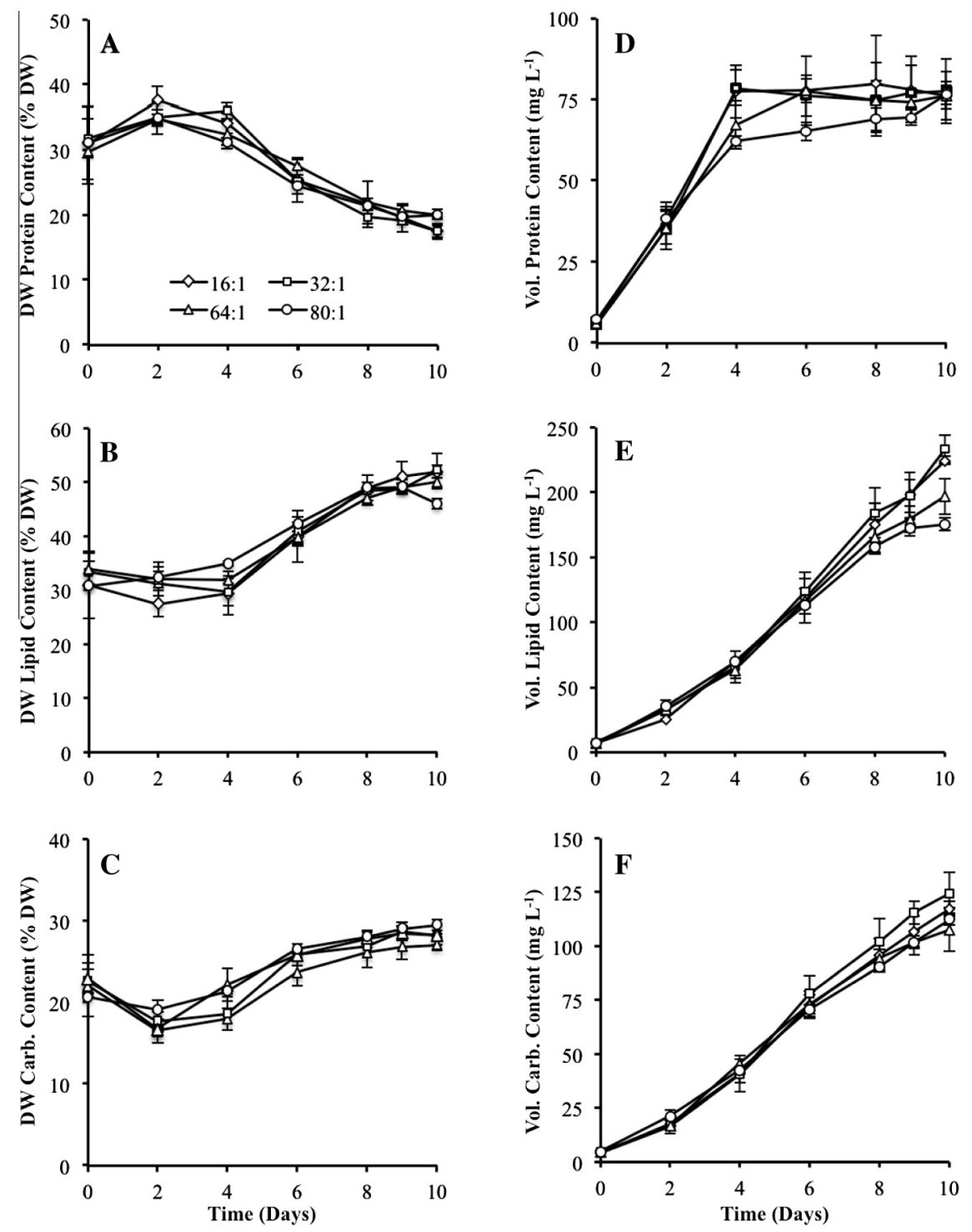

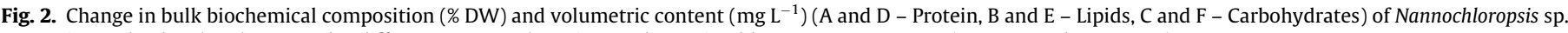
grown in 10-day batch cultures under different N:P supply ratios, as determined by FTIR spectroscopy $(n=3$, error bars $=1$ SD).

$\mathrm{N}$ :P treatment on days 4, 6 and $10(p<0.05)$ and also achieved the greatest carbohydrate content, of $29.5 \%$ DW as carbohydrate by day 10 . There was no difference between the 16:1, 32:1 and 64:1 treatments (\% DW; $p>0.05$ ); furthermore, the volumetric concentration of carbohydrate did not vary significantly between treatments (Fig. 2F; $p>0.05$ ).

Overall, the effect of P-limitation concurrent with N-stress did not significantly effect bulk biochemical composition on a (DW) biomass basis, however, on a per cell basis, the subtle effects of nutrient stress can be seen. The $\mathrm{N}_{\text {cell }}{ }^{-1}$ did not vary significantly between the $16: 1,32: 1$ and $64: 1$ treatments on day 10 of cultivation (Supplementary Table 1; 27-31 $\mu \mathrm{g} \mathrm{N}$ cell $^{-1}$ ), but was much greater in the $80: 1$ ratio ( $53 \mu \mathrm{g} \mathrm{N}$ cell ${ }^{-1}$ ), suggesting that P-deplete cells did not experience as great a level of N-stress as those supplied at high N:P. This would suggest that P-limitation did in fact cause an increase in lipid content per cell; under these conditions Nannochloropsis sp. continued to photosynthetically fix carbon, which was directed towards storage products rather then structural compounds, despite not having decreased $\mathrm{N}$ content per cell to the same level as those in other treatments. This is consistent with the behaviour of Selenastrium minutum (Elrifi and Turpin, 1985, as presented in Flynn, 2008). The larger lipid content per cell also explains the significant increase in cell size seen in the 80:1 treatment compared to the others (Supplementary Table 1).

\subsection{Biomass and lipid yield on phosphorus supply}

The relationship between the quantity of biomass and lipids produced $\left(\mathrm{g} \mathrm{L}^{-1}\right)$ after 10 days and the amount of $\mathrm{P}$ supplied are plotted in Fig. 3A; both show a decreased production at the lower P supply concentrations at N:P ratios 64:1 and 80:1. There were no increases in either the biomass or lipid concentration at $\mathrm{N}$ :P supply ratios lower than $32: 1$, suggesting that lower ratios provided a surplus of $\mathrm{P}$ and did not affect production of biomass and lipids, relative to the amount of $\mathrm{N}$ supplied (here, $10 \mathrm{mg} \mathrm{N} \mathrm{L}^{-1}$ ). There was a high degree of correlation between the supply of $\mathrm{P}$ to cultures and the yield of volumetric lipid production ( $\mathrm{g}$ lipid $\mathrm{L}^{-1}$; Fig. $3 \mathrm{~A}$; $r^{2}=0.889, p \gg 0.001$ ) allowing for predictions to be made based on the $\mathrm{P}$ supply under fixed $\mathrm{N}$ concentrations in this system. At higher $\mathrm{N}$-supply concentrations, where light will become increasingly limiting due to biomass self-shading, the optimal supply $\mathrm{N}: \mathrm{P}$ is expected to be greater again, as the N-nutrient itself is less likely to be fully consumed (Kenny and Flynn, 2014). 

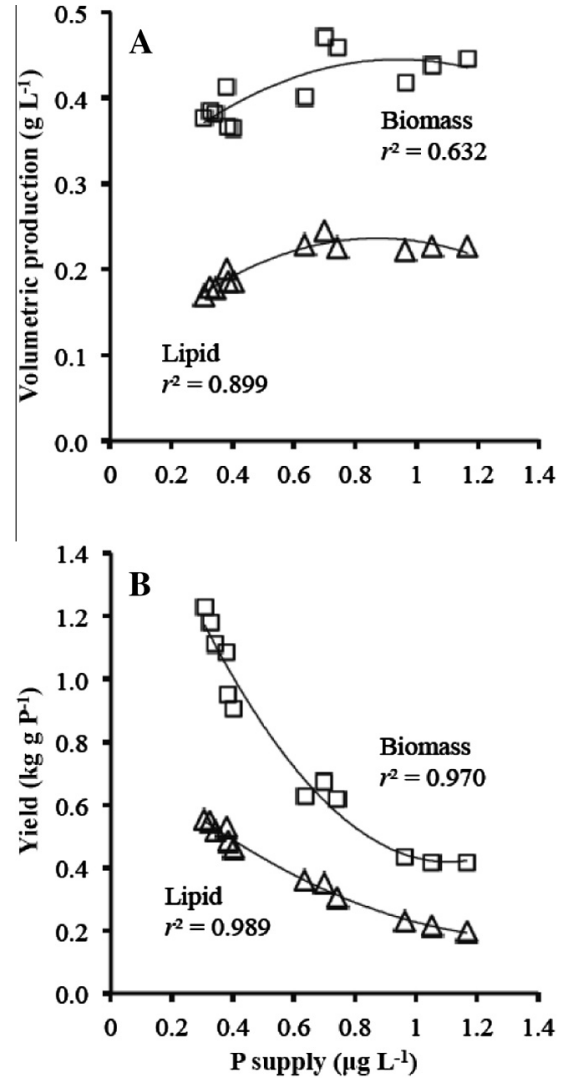

Fig. 3. Relationship between (A) volumetric biomass (squares) and lipid (triangles) production and $P$ supply and $(B)$ the maximum yields of biomass and lipid per unit of $\mathrm{P}$ for different $\mathrm{P}$ supplies of Nannochloropsis sp. grown in 10-day batch cultures. Curves were fitted using a second order polynomial regression. Each data point represents an individual experimental sample taken at day 10 .

In this study, P-specific production was between 0.43 and $1.17 \mathrm{~kg}$ biomass $(\mathrm{g} \mathrm{P})^{-1}$, and 0.21 and $0.54 \mathrm{~kg}$ lipid $(\mathrm{g} \mathrm{P})^{-1}$ across the range of treatments tested (Fig. 3B). Generally high levels of $P$ supply resulted in the lowest yields, as there is little increase in biomass for a higher level of $P$ uptake and accumulation, suggestive of "luxury uptake". These results are comparable with the study of Wu et al. (2013) that achieved yields in the region of 2.1-3.1 kg biomass ( $\mathrm{g} \mathrm{P})^{-1}$ and $0.37-0.83 \mathrm{~kg}$ lipid $(\mathrm{g} \mathrm{P})^{-1}$ in different Chlorella species, but poorer in comparison to a yield of $6.1 \mathrm{~kg}$ biomass $(\mathrm{g} \mathrm{P})^{-1}$ and $1.83 \mathrm{~kg}$ lipid $(\mathrm{g} \mathrm{P})^{-1}$ in Scenedesmus. However, there are two differences in experimental design between the current study and that by Wu et al. (2013): (i) the current study utilised a lower $\mathrm{N}$ media enabling significant $\mathrm{N}$-depletion while concurrently testing P-starvation; (ii) Wu et al. did not include the $\mathrm{P}$ content of the original inoculum in their estimation of P-specific production, leading to possible yield overestimations. Calculations of the biomass yield per unit of $\mathrm{P}$ need to account (as they did here) for the total P used throughout the process, and not just during batch growth in the final largescale reactor. In the current study, the inocula contained a molar biomass $\mathrm{N}: \mathrm{P}$ of $\sim 18$, a value close to the Redfield ratio (16) considered optima (Geider and La Roche, 2002). For the highest supply $\mathrm{N}: \mathrm{P}(80: 1)$, the residual biomass-P in the inocula made a significant contribution to the final biomass $\mathrm{P}$.

\subsection{Linking elemental content to biochemical composition}

The minimum and maximum $\mathrm{N}$ content of Nannochloropsis sp. was approximately $2.6 \%$ and $5.7 \%$ of DW and had a corresponding lipid content of $58 \%$ and $26 \%$, respectively (Fig. 4A). These values were comparable to those in the literature (Adams and Bugbee, 2014). Higher $\mathrm{N}$ and correspondingly lower lipid contents have been recorded by the authors (data not shown) when Nannochloropsis sp. has been grown for longer under more $\mathrm{N}$ replete conditions. The P content of Nannochloropsis sp. in this study ranged from $0.08 \%$ to $0.60 \%$ of $\mathrm{DW}$, resulting in cellular $\mathrm{N}$ :P ranging from 18 to 79 , depending upon treatment and the sampling time point, showing significant deviation from the Redfield ratio of 16 (Geider and La Roche, 2002). Biomass N:P ratios shifted to reflect that of the media $\mathrm{N}: \mathrm{P}$ after 10 days batch culture as would be expected (Flynn, 2010).

Fig. 4A shows the relationship between cellular-N content $(\%$ DW) and the corresponding lipid and carbohydrate content for the different $\mathrm{P}$ regimes. The relationship between $\mathrm{N}$ content and lipid content showed a strong inverse linear relationship for each treatment (Fig. 4A, closed symbols; Table $2 ; r^{2}>0.90, p<0.001$ ), with no significant difference between treatments. When $\mathrm{N}: \mathrm{P}$ treatments were disregarded and the data taken as a single group, there was also a significant correlation between $\mathrm{N}$ and lipid content (Table 2; $r^{2}>0.95, p<0.001$ ). The carbohydrate content of the biomass was also found to correlate highly with $\mathrm{N}$ content (Fig. 4A, open symbols; Table $2 ; r^{2}>0.90, p<0.001$ ), as was also the case with the grouped data (Table $2 ; r^{2}>0.90, p<0.001$ ). The
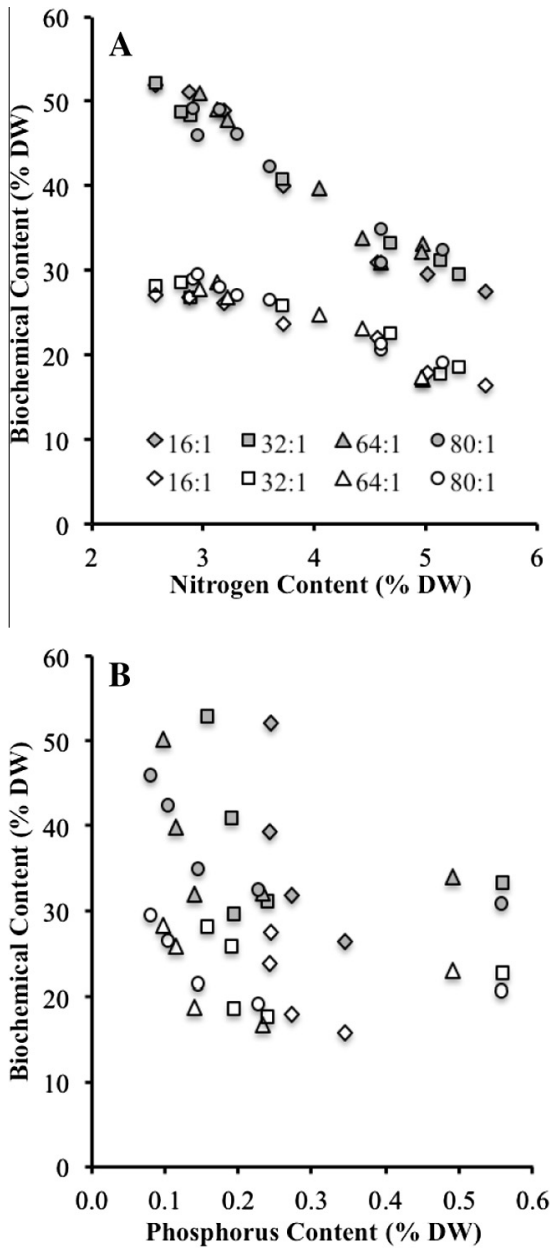

Fig. 4. Relationship between cellular (A) nitrogen or (B) phosphorus content (\% DW) and lipid content (closed symbols) and carbohydrate content (open symbols) for Nannochloropsis sp. grown under different N:P supply ratios and grouped. Each data point represents the average of three repeats at different days of cultivation, representing all growth phases. 
Table 2

Correlation coefficients $\left(r^{2}\right)$ between biomass $\mathrm{N}$ or P content (\% DW) and biomass lipid and carbohydrate content (\% DW) for individual N:P supply ratios and grouped data.

\begin{tabular}{|c|c|c|c|c|}
\hline \multirow[t]{2}{*}{$\mathrm{N}: \mathrm{P}$ supply ratio } & \multicolumn{2}{|c|}{ Nitrogen } & \multicolumn{2}{|c|}{ Phosphorus } \\
\hline & Lipid $^{\text {a }}$ & Carb. $^{\text {b }}$ & Lipid $^{\text {b }}$ & Carb. $^{\text {b }}$ \\
\hline $16: 1$ & 0.96 & 0.96 & 0.67 & 0.77 \\
\hline $32: 1$ & 0.98 & 0.93 & 0.71 & 0.83 \\
\hline $64: 1$ & 0.99 & 0.92 & 0.65 & 0.70 \\
\hline $80: 1$ & 0.93 & 0.99 & 0.94 & 0.94 \\
\hline Grouped & 0.96 & 0.91 & 0.29 & 0.43 \\
\hline
\end{tabular}

Carb. = carbohydrate

a Values were obtained from linear regression.

b Values were obtained from 2nd order polynomial regression.

increase in carbohydrate content from $\mathrm{N}$ replete to $\mathrm{N}$ deplete conditions was lower then that for lipids (1.5-1.7 vs 1.6-1.9-fold; Fig $4 \mathrm{~A})$, suggesting that for every unit change in cellular- $\mathrm{N}$, there was a correspondingly greater change in lipid content over carbohydrate. When lipid and carbohydrate content was related to cellular-P concentration (\% DW) there were no significant relationships for individual treatments, except in the case of the 80:1 using a 2nd order polynomial regression, however for grouped data this relationship was lost (Fig. 4B, Table 2).

There were no correlation between $\mathrm{P}$ and lipid content on a per cell basis. However, there were significant relationships found between $\mathrm{N} \mathrm{cell}^{-1}$ and lipid cell ${ }^{-1}$ for the $16: 1$ and 32:1 treatments $\left(r^{2}>0.90, p<0.001\right)$, but not in the 64:1 and 80:1 treatments. This suggests an interactive effect between $\mathrm{N}$ and $\mathrm{P}$ stresses and the lipid content of Nannochloropsis sp.

Overall, these results represent one of the most detailed appraisals of the effect of $\mathrm{N}$ - and P-limitation on Nannochloropsis sp. bulk biochemical composition, suggesting that intracellular-N was the most significant factor impacting large shifts in composition when grown in batch culture. Despite a decrease in the intracellular-P by up to $75 \%$ through different external concentrations, the same total volume of lipids and carbohydrate are produced by the culture $\left(\mathrm{mg} \mathrm{L}^{-1}\right)$, albeit with significant differences in the cellular levels of both lipids and carbohydrates, suggesting that $\mathrm{P}$ limitation can also bring about an increase in carbon product accumulation (Elrifi and Turpin, 1985; Gong et al., 2012; Liang et al., 2013).

The above mentioned results contrasts with studies that propose that during batch cultivation, plentiful $\mathrm{P}$ is required for lipid accumulation under N-starvation in Chlorella and Scenedesmus species (Chu et al., 2013, 2014). An explanation might be that plentiful $\mathrm{P}$ is required in some species to fully exploit nutrient- $\mathrm{N}$ and eventually deplete their cellular-N pool resulting in lipid accumulation. This further highlights the importance of always measuring the intracellular nutrient concentrations $(\mathrm{C}: \mathrm{N}: \mathrm{P})$ in studies of algal lipid production in fully understanding the degree of nutrient stress and the interactive effect of particular stresses, in this instance $\mathrm{N}$ and $\mathrm{P}$.

The current study would suggest that in Nannochloropsis sp., the P supply could be plentiful or limiting to achieve similarly high levels of lipid accumulation, but more critically that the primary impact of an inadequate $P$ supply is seen in the negative influence on cell division and biomass productivity, which may then ultimately affect overall lipid productivity. The accumulation of lipid (and changes in biochemical content in general) are thus functions of species and strain, and also of the nutrient history and detail of the experimental protocols. Careful experimentation must be made in order to accurately interpret lipid accumulation strategies, ideally with statement of the intracellular nutrient status of the culture. In addition, understanding these relationships is imperative in development of detailed in silico models that can aid identification of optimal conditions and production strategies for growth and desirable biochemical composition (Kenny and Flynn, 2014).

\section{Conclusion}

Nutrient supply is a well-known and critical factor in determining both biomass and lipid productivity in microalgal cultures. Here, it was found that P-limitation alongside $\mathrm{N}$-starvation had a subtle but minimal effect on bulk biochemical composition, but negatively influenced cell division and biomass productivity of Nannochloropsis sp. However, it is also apparent that an N:P ratio of $16: 1$ (the Redfield ratio, generally considered as "optimal") is in surplus of $P$ for biomass production and can be decreased possibly beyond 32:1 without compromising lipid productivity, while offering considerable savings and improving sustainability of microalgal biomass production.

\section{Acknowledgements}

The authors would like to gratefully thank Dr Naomi Ginnever, Dr Alla Silkina, Gemma Webb and all of the CSAR technical team for their help, time and support. The work of Joshua Mayers is funded by the European Structural Funds via a Knowledge Economy Skills Scholarship. The authors would also like to acknowledge the financial support of the INTEREG IVB Northwest Europe programme, via the EnAlgae project.

\section{Appendix A. Supplementary data}

Supplementary data associated with this article can be found, in the online version, at http://dx.doi.org/10.1016/j.biortech.2014. 07.048.

\section{References}

Adams, C., Bugbee, B., 2014. Nitrogen retention and partitioning at the initiation of lipid accumulation in nitrogen-deficient algae. J. Phycol. 50, 356-365.

Andersen, R.A. (Ed.), 2005. Algal Culturing Techniques. Elsevier Academic Press, USA.

Britton, A., Baur, R.O.B., 2010. Phosphorus: a resource in decline. J. Am. Water Work. Assoc., 117-118.

Chu, F.-F., Chu, P.-N., Cai, P.-J., Li, W.-W., Lam, P.K.S., Zeng, R.J., 2013. Phosphorus plays an important role in enhancing biodiesel productivity of Chlorella vulgaris under nitrogen deficiency. Bioresour. Technol. 134, 341-346.

Chu, F.-F., Chu, P.-N., Shen, X.-F., Lam, P.K.S., Zeng, R.J., 2014. Effect of phosphorus on biodiesel production from Scenedesmus obliquus under nitrogen-deficiency stress. Bioresour. Technol. 152, 241-246.

Cordell, D., Drangert, J.-O., White, S., 2009. The story of phosphorus: global food security and food for thought. Glob. Environ. Change 19, 292-305.

Cordell, D., Rosemarin, A., Schröder, J.J., Smit, A.L., 2011. Towards global phosphorus security: a systems framework for phosphorus recovery and reuse options. Chemosphere 84, 747-758.

Elrifi, I.R., Turpin, D.H. 1985. Steady-state luxury consumption and the concept of optimum nutrient ratios: a study with phosphate and nitrate limited Selenastrum minutum (Chlorophyta). J. Phycol. 21, 592-602.

Elser, J., Bennett, E., 2011. Phosphorus cycle: a broken biogeochemical cycle. Nature 478, 29-31.

European Fertiliser Manufacturers' Association, 2000. Production of NPK fertilisers by the mixed acid route in Best Available Practices for Pollution Prevention and Control in the European Fertilizer Industry, Brussels.

Flynn, K.J., 2008. The importance of the form of the quota curve and control of nonlimiting nutrient transport in phytoplankton models. J. Plank. Res. 30, 423-438.

Flynn, K.J., 2010. Do external resource ratios matter? J. Mar. Syst. 83, 170-180.

Geider, R., La Roche, J., 2002. Redfield revisited: variability of C:N:P in marine microalgae and its biochemical basis. Eur. J. Phycol. 37, 1-17.

Gerardo, M.L., Oatley-Radcliffe, D.L., Lovitt, R.W., 2014. Integration of membrane technology in microalgae biorefineries. J. Memb. Sci. 464, 86-99.

Gong, Y., Guo, X., Wan, X., Liang, Z., Jiang, M., 2012. Triacylglycerol accumulation and change in fatty acid content of four marine oleaginous microalgae under nutrient limitation and at different culture ages. J. Basic Microbiol. 53, 29-36.

Greenwell, H.C., Laurens, L.M.L., Shields, R.J., Lovitt, R.W., Flynn, K.J., 2010. Placing microalgae on the biofuels priority list: a review of the technological challenges. J. R. Soc. Interface 7, 703-726. 
Handler, R.M., Canter, C.E., Kalnes, T.N., Lupton, F.S., Kholiqov, O., Shonnard, D.R. Blowers, P., 2012. Evaluation of environmental impacts from microalgae cultivation in open-air raceway ponds: analysis of the prior literature and investigation of wide variance in predicted impacts. Algal Res. 1, 83-92.

Historical Phosphate Rock Prices and Price Chart - InvestmentMine [WWW Document], n.d. URL <http://www.infomine.com/investment/metal-prices/ phosphate-rock/all/> (accessed 2.19.14).

Hu, H., Gao, K., 2006. Response of growth and fatty acid compositions of Nannochloropsis sp. to environmental factors under elevated $\mathrm{CO} 2$ concentration. Biotechnol. Lett. 28, 987-992.

Johnson, M.C., Palou-Rivera, I., Frank, E.D., 2013. Energy consumption during the manufacture of nutrients for algae cultivation. Algal Res. 2, 426-436.

Kenny, P., Flynn, K.J., 2014. In silico optimisation for production of biomass and biofuel feedstocks from microalgae. J. Appl. Phycol.. http://dx.doi.org/10.1007/ s10811-014-0342-2.

Liang, K., Zhang, Q., Gu, M., Cong, W., 2013. Effect of phosphorus on lipid accumulation in freshwater microalga Chlorella sp.. J. Appl. Phycol. 25, 311-318.

Mayers, J.J., Flynn, K.J., Shields, R.J., 2013. Rapid determination of bulk microalgal biochemical composition by Fourier-Transform Infrared Spectroscopy. Bioresour. Technol. 148, 215-220.

Moseley, J., Grossman, A.R., 2009. Phosphate metabolism and response to phosphate deficiency. In: Stern, D. (Ed.), The Chlamydomonas Sourcebook: Organellar and Metabolic Processes, vol. 2. Academic Press, New York, pp. 189209.

National Research Council of the National Academies, 2012. Sustainable Development of Algal Biofuels in the United States. The National Academies Press, Washington, D.C..
Powell, N., Shilton, A., Chisti, Y., Pratt, S., 2009. Towards a luxury uptake process via microalgae - defining the polyphosphate dynamics. Water Res. 43, 42074213

Roopnarain, A., Gray, V.M., Sym, S.D., 2014. Phosphorus limitation and starvation effects on cell growth and lipid accumulation in Isochrysis galbana U4 for biodiesel production. Bioresour. Technol. 156, 408-411.

Ruangsomboon, S., Ganmanee, M., Choochote, S., 2013. Effects of different nitrogen, phosphorus, and iron concentrations and salinity on lipid production in newly isolate strain of the tropical green microalga, Scenedesmus dimorphus KMITL. J. Appl. Phycol. 25, 867-874.

Shilton, A.N., Blank, L.M., Nano, F.E., Rodríguez, J.F., Elser, J.J., 2012. Phosphorus: a limiting nutrient for humanity? Curr. Opin. Biotechnol. 23, 833-838.

Sills, D.L., Paramita, V., Franke, M.J., Johnson, M.C., Akabas, T.M., Greene, C.H., Tester, J.W., 2013. Quantitative uncertainty analysis of Life Cycle Assessment for algal biofuel production. Environ. Sci. Technol. 47, 687-694.

Strickland, J.D.H., Parsons, T.R., 1968. Determination of reactive phosphorus. In: Strickland, J.D.H., Parsons, T.R. (Eds.), A Practical Handbook of Sewater Analysis. Fishers Research Board of Canada, Ottawa, pp. 49-56.

Wu, Y.-H., Yin, Y. Xin, L., Hong-Ying , H., Zhen-Feng S., 2012. Biomass production of a Scenedesmus sp. under phosphorous-starvation cultivation condition. Bioresour. Technol. 112, 193-198.

Wu, Y.-H., Yin, Y., Hong-Ying, H., 2013. Potential biomass yield per phosphorus and lipid accumulation property of seven microalgal species. Bioresour. Technol. 130, 599-602.

Yang, J., Xu, M., Zhang, X., Hu, Q., Sommerfeld, M., Chen, Y., 2011. Life-cycle analysis on biodiesel production from microalgae: water footprint and nutrients balance. Bioresour. Technol. 102, 159-165. 